\section{A FELELŐSSÉGBIZTOSÍTÁS SZEREPE A DRÓNKÁROK VISSZASZORÍTÁSÁBAN ÉS A KÁROSULTAK HELYZETÉNEK MEGKÖNNYÍTÉSÉBEN}

Dr. Miskolczi Bodnár Péter (Károli Gáspár Református Egyetem, tanszékvezetö egyetemi tanár)

\section{ÖSSZEFOGLALÓ}

A tanulmány a drónbalesetekhez kapcsolódó felelősségbiztositás Európai Közösségben és Magyarországon érvényesülő szabályait vizsgálja. A drónok működtetése kevesebb kockázattal jár, mint a repülőgépeké. A repülőgépekre vonatkozó felelősségbiztosítás kiterjed az utasokat ért és a fuvarozott küldeményekben keletkezett károkra. A drónokra vonatkozó felelősségbiztosításnak nem kell ilyen károkra fedezetet biztosítani. A drónokra vonatkozó részletszabályok hiányoznak a magyar jogból. Ilyen normák megalkotását az Európai Bizottság tervezi. A drónokra vonatkozó felelősségbiztosítás szabályozása nagyon sürgős lenne, mivel a felelősségbiztosítás fontos szerepet játszik a balesetek megelőzésében és a károk megtéritésében.

\section{SUMMARY}

The study examines the terms of European and Hungarian liability insurance covering the risk of drone-accidents. Activity of drones is less risky, than flying of planes. Liability insurance for airplanes covers damages caused to passengers and carried goods. Liability insurance for unmanned aerial vehicles requires no cover for such kind of damages. Detailed regulation of drones is still missing from the Hungarian legal system. Creation of relevant regulation is on the agenda of the European Commission. Legislation on drone's liability insurance would be extremely urgent, because liability insurance has an important role to prevent accidents and compensate damages.

Kulcsszavak: drón/UAV, felelösségbiztosítás, kockázat

Keywords: drone/UAV, liability insurance, risk

\section{JEL: K12, K19, O33}

DOI: $10.18530 / \mathrm{BK} .2018 .1 .22$

http://dx.doi.org/1018530/BK.2018.1.22

\section{Bevezetés - A drónok használatának előnyei és potenciális hátrányai}

A drónok hadi célra kifejlesztett eszközök, de a honvédelmen túl számos további állami feladat ${ }^{1}$ ellátásában is célszerűen felhasználhatók, így például tömegeket megmozgató rendezvények szervezése során, erdőtüzek, árvizek megfigyelésében. A kereskedelmi hasznosítás jelenti a drónok felhasználásának harmadik nagy és folyamatosan bővülö területét. Használják ezeket a légi járműveket mezőgazdasági területek megfigyelésére, a növényi kultúrákat veszélyeztető betegségek gyors észlelésére, permetezésre, továbbá vezetékek megfigyelésében, ingatlanőrzésben is jól hasznosíthatók, és kiváló felvételek készíthetők velük, amelyeket a média és a filmgyártás is értékel. Legtöbben mégis rekreációs funkciójukról ismerik a drónokat, nevezetesen, hogy lehet reptetni őket, és madártávlatból is láthatjuk velük a világot.

A drónok sokrétű felhasználási lehetőségeit azért indokolt megemlíteni, mert a tanulmány a drónok használatához kapcsolódó veszélyekről és ezek csökkentéséről szól, célszerű tehát elkerülni azt, hogy az olvasóban egyoldalúan negatív kép alakuljon ki. Tény, hogy a drónok - mint minden jármü - balesetet idézhetnek elö, és ennek következtében kárt okozhatnak. Erről bővebben tudna mesélni az az autós, akinek Budapesten a Szabadság hídon egy lezuhanó drón betörte a szélvédöjét, vagy Enrique Iglesias, aki kénytelen volt félbehagyni egy koncertjét, hogy kórházban lássák el a sebét, amelyet egy rajongója által a színpadra röptetett drón okozott. A Boeing repülőgépgyár komolyan foglalkozik azzal a tervvel, hogy lézerfegyverrel szereli fel az általa polgári célra készített repülögépeket, hogy a le- és felszállás idején a géphez fenyegető közelségbe kerülő drónokat megsemmisíthessék, mert 2017-ben London fölött összeütközött egy gépük valamivel, amirool azt gyanították, hogy drón lehetett. ${ }^{2}$

A tanulmány döntően a drónok által okozott balesetek miatti felelősséghez kapcsolódó felelősségbiztosítás kérdéseit vizsgálja.

\section{A felelősségbiztosítás szerepe drónok baleseteiből eredő károk esetén}

A felelősségbiztosítás a biztosítási eseménynek minősülő károk bekövetkezése és az értük való felelősség esetén rövid távon elsősorban a kárt elszenvedőre, hosszabb távon pedig a kárért felelős személyre gyakorolt hatása miatt játszhat fontos szerepet. ${ }^{3}$

\subsection{A felelősségbiztosítás szerepe a tényleges drónkárosultak szempontjából}

A felelösségbiztosítás jórészt leveszi a károsult válláról annak a kockázatát, hogy a kárért felelős személy fizetésképtelen. ${ }^{4}$ „A felelősségbiztosítás a kárkötelem kielégítésének biztosítéka: a kötelezetti oldal megerősítése, amely az eredeti kötelmi helyzet változatlan fenntartása és alanyváltozás nélkül teszi lehetővé harmadik személy, a felelösségbiztosító teljesítését a kötelezett helyett." ${ }^{\text {"’ }}$ Abban az esetben, ha egyértelmüen megállapítható a felelős személye, és ő rendelkezik felelősségbiztosítással, akkor a biztosító fizetése révén a károsult helyzete rendeződik annak ellenére, hogy a károkozótól sohasem jutott volna kártérítéshez. 


\subsection{A felelősségbiztosítás szerepe a károkozók szempontjából}

A biztosítási jog hosszabb távon befolyásolhatja a drónok üzemeltetőinek a magatartását. A biztositók alacsonyabb biztosítási díjak mellett kötnek felelősségbiztositási szerződést az olyan drónüzemeltetökkel, akik több ismerettel rendelkeznek, hosszabb ideje balesetmentesen tevékenykednek. A kiadások alacsonyabb szintje további ismeretek megszerzésére, nagyobb fokú gondosságra, hosszabb távon jobban felszerelt, biztonságosabb drónok megvásárlására ösztönözheti a költségérzékeny drónhasználókat. Ezen ösztönzés révén a biztosítás közrehat a drónkárok megelőzésében.

A biztositás a regressz igények által is befolyásolhatja a potenciális károkozók magatartását. Annak a tudata, hogy a biztosító a felelősségbiztosítás alapján a károsultnak fizetett összeg megtéritését bizonyos esetekben követelheti a kárért felelős személytől, e személyt a károk megelőzésére ösztönözheti.

Jelenleg Magyarországon csekély a drónokkal kapcsolatos felelősségbiztosítási szerzódés megkötésére irányuló hajlandóság.

A drónok müködtetőire gyakorolt hatás révén a felelősségbiztosítás csökkenti annak a valószínűségét, hogy az üzemben tartók károkozókká váljanak, ezáltal kedvezően érinti mindazokat, akik egy kevésbé körültekintő drónhasználat esetén kárt szenvedhetnének.

Jelenleg Magyarországon csekély a drónokkal kapcsolatos felelősségbiztosítási szerződés megkötésére irányuló hajlandóság.

A biztosítók ma Magyarországon nem kínálnak széles választékot a drónok által okozott károkért való felelősség biztosítására. Hobbicélú drónhasználat során okozott károkért való felelősségbiztosításra nem is lehet minden hazánkban müködő biztosítóval szerződést kötni.

A potenciális károkozók sem sietnek felelősségbiztosítási szerződést kötni, mivel az érintettek - alappal vagy alaptalanul - bíznak abban, hogy nem okoznak balesetet, így a felelösségbiztosítás keretében a biztosítónak fizetett díjat megtakarítható kiadásnak tekintik.

Ilyen körülmények között a felelösségbiztosítás prevenciós hatása jelenleg elhanyagolható mértékü. Célszerű lenne ezen változtatni.

\section{A drónkárokért való felelösségbiztosítás formái}

A felelősségbiztositás jellemzően egy önként választható komplex biztosítási csomag részeként vagy jogszabály által kötelezővé tett biztosítási formaként létezhet.

A drónokkal okozott károkért való felelősség beilleszthető lenne egy biztosítási csomagba, amely a házat, a lakás berendezési tárgyait védené vagyonbiztosításként, és emellett bizonyos felelősségbiztosítási elemeket is tartalmazna. A tulajdonos által el nem takarított havas járdán elcsúszó gyalogost ért kár, a tetőről lezúduló hó miatt az ott parkoló autóban keletkező kár, a szerződő fél gyermeke által a szomszéd betört ablakában keletkező kár mellett a ház lakói által irányított drónokkal okozott kárért való felelősség is biztosítási eseménynek minősülhetne. Kicsinek látom azonban annak a piaci realitását, hogy a biztosítók egy létező komplex szolgáltatásnak a drónkárok miatti felelősséggel való kiegészítés révén érdemi díjemelést tudnának elérni, így a drónokkal okozott károkért való felelősséget nehéznek látszik beilleszteni egy meglévő biztosítási csomagba.

Jelen tanulmányban ezért a másik megoldást vizsgáljuk meg, nevezetesen annak lehetőségét járjuk körbe, hogy jogszabály tegye kötelezővé azt, hogy a drónok üzemeltetői kössenek felelősségbiztosítást.

\section{Felelösségbiztosítási kötelezettség}

A drónokra vonatkozó kötelező felelősségbiztosítást nem bevezetni, hanem kiterjeszteni szükséges. Bizonyos drónok jelenleg is csak felelősségbiztosítás birtokában repülhetnek. A felelösségbiztosítási kötelezettség az uniós szabályozásban gyökerezik, de a tagállami jogok áttekintése szintén szükségesnek látszik. Az Európai Unió és a tagállamok között ugyanis eredetileg hatáskörmegosztás létezett a légi járművekre vonatkozó szabályozás - köztük a drónokra és a drónok felelősségbiztosítására vonatkozó normák - megalkotása terén. A hatáskörmegosztás alapján a 150 kg felszálló össztömeget meghaladó repülőgépekre és más légi járművekre közösségi normák vonatkoztak, míg a kisebb tömegü légijárművekre - föszabály szerint - a tagállamok alkothattak normákat. A kis légi járművek szabályozása még 2018 elején is tagállami hatáskörbe tartozik. A drónok sokfélék, de döntő többségük a repülőgépeknél jóval kisebb felszálló tömeggel rendelkezik ${ }^{6}$ így az uniós normák eredetileg nem vonatkoztak a drónok legnagyobb részére.

\subsection{EU-s szabályok}

\subsubsection{A légi jármüvekre vonatkozó szabályok változása a drónok tekintetében}

Az Európai Unió repüléssel kapcsolatos rendeletei ${ }^{7}$ nyomán kialakult, a 150 kg felszálló tömegnél elválasztott megosztott szabályozási hatáskör napjai meg vannak számlálva. Az Európai Unió repülésbiztonsági politikája jelenleg komoly változáson megy át. Egyrészt célul tűzték ki a drónok beillesztését a repülésbiztonságba, és meg is tették az első lépéseket ebbe az irányba. ${ }^{8}$ Másrészt felismerték a drónok gazdasági jelentőségét, buzdítják a drónfejlesztésre irányuló kutatásokat, és szorgalmazzák a drónok gazdasági (kereskedelmi) célú felhasználásának elterjesztését. E változásokkal párhuzamosan határozott törekvés figyelhető meg a drónhasználat feltételeinek egységesítésére, ami azt célozza, hogy ezen a területen is egységes belső piac jöjjön létre a tagállami szabályozás által kialakult jelenlegi sokszínűség helyett. Ennek érdekében 2018-tól valamennyi légi járműre - így a 150 kg felszálló tömegnél kisebbekre is - egységes európai szabályok bevezetését tervezik. A tagállamok elfogadni látszanak speciális szabályozási hatáskörük központosítását. 
3.1.2. Alapvetően légi jármüvekre, de szük körben drónokra is vonatkozó, hatályos felelősségbiztosítási követelmények

A légi fuvarozók engedélyezéséről szóló, 1992. július 23-i 2407/92/EGK tanácsi rendelet a légi fuvarozók számára baleseti felelősségbiztosítás megkötését írta elő, de nem határozta meg a biztosítás minimális összegét és feltételeit.

Az Európai Polgári Repülési Konferencia 2000. december 13-án elfogadta az utasokra és harmadik felekre vonatkozó felelősségbiztosítás minimális szintjéről szóló ECAC/25/1 határozatot, amelyet 2002. november 27-én módosítottak.

Az Európai Parlamentnek és a Tanácsnak a légi fuvarozókra és légi járművek üzemben tartóira vonatkozó biztosítási követelményekről szóló 2004. április 21-i 785/2004/EK rendelete ${ }^{9}$ szerint „Minimális biztosításról kell gondoskodni olyan helyzetekben, amikor a légi fuvarozó vagy a légi járművek üzemben tartója nemzetközi egyezmények, a közösségi vagy a nemzeti jog szabályai értelmében felelősséggel tartozik az utasok, a poggyász, a rakomány vagy harmadik felek tekintetében, az említett szabályokkal való szembehelyezkedés nélkül.”10 A légi fuvarozók számára elő kell írni annak bizonyítását, hogy e rendelet rendelkezéseinek megfelelően minden esetben betartják a felelösségbiztosítási minimumkövetelményeket. ${ }^{11} \mathrm{~A}$ rendeletnek az a célkitüzése, hogy olyan biztosítási minimumkövetelményeket vezessen be, amelyek a verseny torzulásának csökkentésével hozzájárulnak a belső légi közlekedési piac célkitűzéseinek eléréséhez. ${ }^{12}$ A biztosítási szerződés megkötésének a kötelezettsége az utasokat ért, továbbá a poggyászukban, a rakományban keletkezett károkra és a harmadik feleknek okozott károkra vonatkozik, akkor is, ha a káresemény háborús cselekmények, terrorizmus, gépeltérítés következtében történt. ${ }^{13} \mathrm{Az}$ 1008/2008/EK rendelet 11. cikke szerint a 785/2004/EK rendeletben foglaltakon túl a légi fuvarozónak a postai küldeményekre vonatkozóan is baleseti felelősségbiztosítással kell rendelkeznie.

A drónok ma még nem szállítanak utasokat, rakományt és postai küldeményeket ${ }^{14}$, így esetükben a harmadik személyeknek okozott károk biztosítására koncentrálhatunk. Harmadik felek tekintetében a biztosításnak ki kell terjednie balesetből eredő halálesetre, személyi sérülésre és vagyoni kárra. ${ }^{15} \mathrm{Az}$ uniós felelősségbiztosítási elvárások egyrészt az $500 \mathrm{~kg}$ fölötti drónokra ${ }^{16}$, másrészt a 20-500 kg közötti kereskedelmi célú17 drónokra vonatkoznak. A harmadik felekre vonatkozó felelősség tekintetében a biztosítási fedezet minimális mértéke a 7. cikk (1) bekezdése alapján

$500 \mathrm{~kg}$ MTOM alatt 0,75 millió SDR ${ }^{18}$

$1000 \mathrm{~kg}$ MTOM alatt 1,5 millió SDR

$2700 \mathrm{~kg}$ MTOM alatt 3 millió SDR

$6000 \mathrm{~kg}$ MTOM alatt 7 millió SDR

\section{Magyar helyzet}

A magyar helyzet több szempontból is ellentmondásos.

\subsection{Felelősségbiztosítási kötelezettség}

A Légiközlekedésről szóló törvénynek ${ }^{19}$ (a továbbiakban Lt.) a közelmúltban történő módosítása óta hazánk is azon tagállamok közé tartozik, amelyek megkövetelik a felelősségbiztosítást. Valójában többes követelmény létezik.

Az Lt. kifejezetten nevesíti a pilóta nélküli légi járművek (ez a drónok hivatalos elnevezése) üzemben tartását olyan tevékenységként, amely - harmadik személynek okozott kár megtéritése céljából - felelősségbiztosítási fedezet fennállása esetén végezhető. Az Lt. 69. \$ (1) bekezdése szerint „A nyilvános repülötér, a lajstromba bejegyzett polgári légi jármü, a repülőeszköz és pilóta nélküli légi jármü üzemben tartása, valamint polgári légi forgalmi irányitó szolgálat által légi forgalmi irányitói tevékenység - harmadik személynek okozott kár megtéritése céljából - felelösségbiztositási fedezet fennállása esetén végezhetö."

Az Lt. a légiközlekedési tevékenység végzéséhez szükséges engedély megadási feltételeként is említi azt, hogy a kérelmezőnek megfelelő felelősségbiztosítási fedezettel kell rendelkeznie. Az Lt. 69. \$ (2) bekezdés első mondata szerint ... légiközlekedési tevékenység végzésére a „22. \$ szerinti, a légiközlekedési hatóság hatáskörébe tartozó engedély megadásához és érvényben tartásához a kérelmezönek megfelelö felelösségbiztositási fedezettel kell rendelkeznie."

\subsection{A kötelezö felelősségbiztosítás részletszabályainak részleges hiánya}

a) A végrehajtási rendelet hiánya

Az Lt. 70. \$-a szerint A kötelező felelősségbiztositás szabályait a Kormány rendeletben határozza meg.

A magyar helyzetkép negatív vonása, hogy a kötelező felelősségbiztosítás szabályait tartalmazó kormányrendelet megalkotására nem került sor. Valószínủleg a jövőben sem jön létre ilyen norma, mert a jogalkotó - látva az Európai Unió szabályalkotási törekvéseit - a hátralévo", rövidnek vélelmezett időre nem kívánt olyan kormányrendeletet hatályba léptetni, amelyet előre láthatóan rövidesen módosítani kell.

\section{b) Az EU-szabályok kötelező ereje}

Speciális magyar szabályok hiányában a közösségi normák irányadók, amelyek közül egyesekre az Lt. kifejezetten felhívja a figyelmet. Az Lt. a gazdasági célú légiközlekedési tevékenység végzéséhez szükséges engedély feltételeként az európai követelményeknek megfelelő felelősségbiztositást ír elő. Az Lt. 69.\$ (2) bekezdés második mondata szerint „A gazdasági célú légiközlekedési tevékenység (71. \$27. pont) végzésére vonatkozó engedély abban az esetben adható, illetve tartható érvényben, ha a kérelmezö az 1008/2008/EK rendelet 11. cikkének megfelelöen felelösségbiztositással rendelkezik." Gazdasági célú drónhasználat esetén tehát a magyar szabály a szükséges engedély feltételeként az európai követelményeknek megfelelő felelősségbiztosítás meglétét írja elő. 


\section{3. Értékelés}

A felelősségbiztosítási kötelezettséget megkövetelő magyar szabályok létét a hazai jogalkotási helyzet pozitív vonásaként értékeljük, még akkor is, ha a kötelező felelősségbiztosítást már a közösségi normák is elöírták. Előfordulhat ugyanis az a helyzet, hogy a kötelezettek egy hazai jogi normából hamarabb szereznek tudomást arról, hogy kötelesek felelősségbiztosítást kötni, mint egy közösségi szabályból.

Hiányosságként értékeljük viszont azt, hogy nem lépett hatályba a drónbiztositásra vonatkozó részletszabályokat tartalmazó rendelet.

Megítélésünk szerint részben előnyös, részben hátrányos az, hogy az Lt. a gazdasági célú légiközlekedési tevékenység végzéséhez szükséges engedély feltételeként az európai követelményeknek megfelelő felelősségbiztosítást ír elő. Előnyként azt említhetjük, hogy ebben a körben nincs joghézag, egyértelműek a követelmények. A drónok üzemeltetői számára azonban hátrányt jelent az, hogy a biztosítási fedezetnek az EU által a repülőgépekre előirt mértékűnek kell lenni. Könnyen belátható, hogy a drónok üzemben tartói számára két szempontból is indokolatlanul magasak a követelmények. Egy csekély tömegü, alacsonyan, kis sebességgel repülő drón károkozó képessége kisebb, mint egy repülőgépé. A repülőgépek esetén a biztosítási fedezet mértékének meghatározásakor az EU jogalkotói figyelembe vették a repülőgép által szállított utasokat ért károkért és a fuvarozott küldeményekben keletkező kárért való felelősséget is, mely kockázati tényezőket drónok esetén ma még figyelmen kívül kellene hagyni.

\subsection{Jövőkép}

A közeljövőben nem várható, hogy Magyarországon megalkotásra kerülne egy olyan végrehaitási szabály, amely a drónokra vonatkozó követelményeket széles körüen rögzítené. Van logika ugyanis abban a megközelítésben, hogy nem célszerủ a $150 \mathrm{~kg}$ felszálló össztömeg alatti légi járművekre vonatkozó általános szabályokat rövid távra hatályba léptetni, majd az EU-norma megalkotását követően hatályon kívül helyezni. Más kérdés, hogy erős kételyeink vannak a tekintetben, hogy 2018-ban megalkotásra kerülne az a közösségi norma, amely miatt a magyar jogalkotó „visszavonulót fújt”. Megítélésünk szerint a felelősségbiztosítás kérdését külön kellene kezelni a drónokra vonatkozó többi szabálytól, mivel a halogatással a jogalkotó lemond a kötelező felelősségbiztosítás reparációs és prevenciós szerepéről, és védtelenül hagyja a potenciális drónkárosultakat.

Speciális magyar szabályok hiányában annak a reményünknek adhatunk hangot, hogy az Európai Unió gyorsan megalkotja a $150 \mathrm{~kg}$ alatti és fölötti légi járművekre vonatkozó egységes szabályokat, és ezáltal megszünteti a hazánkban megfigyelhető joghézagot. Remélhetőleg a közösségi norma elkülöníti egymástól a repülőgépekre és a drónokra vonatkozó biztosítási követelményeket. Célszerűnek látnánk, ha a kötelező felelősségbiztosításban foglalt biztosítási összeg minimumának mértékét olyan módon határoznák meg, hogy a sávok megalkotásakor többféle szempontot vennének figyelembe. A felszálló össztömeg kiinduló szempontként változatlanul megfelelőnek látszik, feltéve, hogy a sávok számát jelentősen megnövelik. A kereskedelmi célú drónok felelősségbiztosítása magasabb kellene, hogy legyen, mint a rekreációs célra használt drónoké. Végül a távolabbi jövőben külön díjtételek megalkotása lesz célszerű a teherszállító és a személyszállító drónokra.

\section{LÁBJEGYZETEK}

'Tanulmányunk nem foglalkozik azzal a kérdéskörrel, hogy a drónok terrorista célra is felhasználhatók, mivel az ilyen magatartásokat a felelösségbiztositás nem képes megelőzni, és a károk megtéritésében sem játszik szerepet. A kérdéskörrel részletesen foglalkozik Hergert Ottó: Terrorizmus és biztositás, Biztositás és Kockázat 2017. 2. pp. 82-00.

${ }^{2} \mathrm{~A}$ közlekedési balesetek okozásán túl a drónok a magánéletre is veszélyt jelentenek. A személyiségvédelem kérdéseinek kifejtését azonban a terjedelmi korlátok nem teszik lehetővé.

ovotni Zoltán: A biztositasisi szerzodések joga, Bp. 1993., Takáts Péter: A biztositási szerződési jog úiraszabályozása, Biztositási Szemle 2005. 1. szám pp. 10-20., Ujváriné Antal Edit: Biztositási szerződés, Barta - Fazakas - Harsányi - Miskolczi Bodnár - Szuchy - Ujváriné: Kereskedelmi szerződések alapvető típusai, 2. átdolgozott kiadás, Patrocinium Budapest 2016. pp. 221-276., Ujváriné Antal Edit: A biztositási törvény és a polgári jog kapcsolodási pontjai, Jogtudományi Közlöny 1996. junius pp. 236-244.

'Lábady Tamás: Felelósség a szerzodesen kivul okozott károkert es a biztositasis szerzodés az ujj Ptk.-ban, Polgári jogi Kodifikáció 2001. 11. Un. 4 sam (1) Z

rész: A felelőssé́biziztositás, Biztositási Oktatási Intézet, Szolnok, 1994.10

tht a drónok 99\%-a 2 kg alatti tömegủ volt (Steer Davies Gleave által 2014 novemberében készitett tanulmány az Európai Bizottság számára, 18. old.)

`A légi fuvarozók engedélyezéséról szóló 1992. július 23-i 2407/92/EGK tanácsi rendelet és az Európai Parlament és a Tanács 2008. február 20-i 216/2008/EK rendelete a polgári repülés közös szabályairól és az Európai Repülésbiztonsági Ügynökség létrehozásáról. 'A Bizottsag 2014. április 8-i közleménye COM(2014)0207 Uj korszak a légi közlekedésben -

A légiközlekedési piac megnyitása a távirányított légijärmürendszerek biztonságos felhasználásáról

${ }^{9} E z t$ a rendeletet a Szerződés hatálya alá tartozó bármely tagállam területén belül, területére, területéről vagy területe felett repülést végzỏ valamennyi légifuvarozóra és légijármü-üzembentartóra kell alkalmazni. 2. cikk (1)

${ }^{10} \mathrm{~L} 13$. preambulum bekezdés

"17. preambulum bekezdés 1 . mondat

1224. preambulum bekezdés 1 . mond

${ }^{13} \mathrm{~A}$ 14. cikk (1) bekezdés

"Reklámcélú, ,csúsztatásnak” bizonyult az Amazon 2017. évi bejelentése, mely szerint sor került az első csomag drónnal valókiszállitására de a drónok esetén is belátható időn belül aktuálissá válik majd a postai küldemények és más rakományok biztositása, és talán a nem "14. preambulum bekezdés 3 . mondat

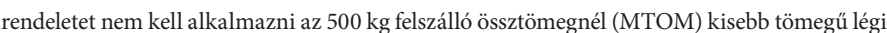

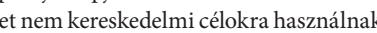

enység a 3. cikk i) pontja szerint az ellenszolgáltatás fejében végzett tevékenysés.

"Idoöközben az euró lépett az elszámolás i egység helyébe.

\section{IRODALOMJEGYZEKK}

Hergert Ottó: Terrorizmus és biztositás. Biztositás és Kockázat 2017. 2 pp 82-100.

Lábady Tamás: Felelösség a szerzớdésen kívül okozott károkért és a biztositási szerződés az új Ptk.-ban, Polgári jogi Kodifikáció 2001. III. évf. 4-5 szám pp. $42-53$

Novotni Zoltán: A biztositási szerzzódések joga, Bp. 1993.

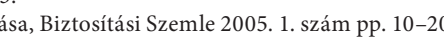

Ujváriné Antal Edit: Biztositásis szerződés, Barta - Fazekas - Harsányi - Miskolczi Bodnár - Szuchy - Ujváriné: Kereskedelmi szerződések alapvető típusai. 2. átdolgozott kiadás, Patrocinium Budapest 2016. pp. 221-276.,

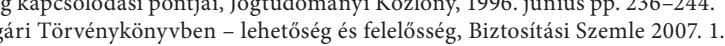
szám pp. 10-33. 